\title{
KARAKTERISTIK LIMBAH KULIT BIJI KAKAO PROSES BIODEGRADASI MENGGUNAKAN JAMUR PELAPUK PUTIH Phanerochaete chrysosporium
}

\author{
Mita Ramadiyanti*1, Triyana Ulfah ${ }^{2}$ \\ 1,2Program Studi Teknologi Hasil Pertanian Jurusan Pertanian Universitas Bandung \\ Raya,Bandung, Indonesia \\ e-mail : ${ }^{1}$ mitamey5@gmail.com
}

\begin{abstract}
ABSTRAK
Limbah kulit biji kakao memiliki potensi kimia seperti kandungan serat lignoselulosa, kandungan protein, kandungan karbohidrat, kandungan theobromine, kandungan cafein, kandungan tannin. Kulit biji kakao memiliki kandungan serat lignoselulosa yang tinggi mencapai 25,10\%. Kandungan serat lignoselulosa tersebut berpotensi untuk dijadikan tempat hidup bagi Phanerochaete chrysosporium untuk hidup dan berkembang biak mendegradasi secara bilogi untuk menghasilkan enzim lakase. Enzim lakase memiliki fungsi yang luas dan kebutuhan akan enzim ini meningkat, namun kendala yang timbul adalah harga enzim lakase yang timggi dan sulit didapatkan. Karakterisasi limbah kulit biji kakao diawali dengan proses pengecilan ukuran bahan baku kulit biji kakao, biodegradasi menggunkan Phanerochaete chrysosporium dengan metode solid state fermentation. Phanerochaete chrysosporium mampu mendegradasi lignin, selulosa dan hemiselulosa dengan menghasilkan enzim lakase. Analisis stuktur dan morfologi menggunakan Scanning electron micriskopy (SEM), spektrofotometer, dan colorimeter. Tujuan dari penelitian ini adalah untuk mengetahui karakterisasi kulit biji kakao secara fisik dan kimia serta menghasilkan enzim lakase. Metode penelitian dimulai dengan studi pendahuluan melalui observasi, studi pustaka untuk merumuskan masalah, dan pengumpulan data. Hasil penelitian menunjukan bahwa hasil dari SEM struktur kulit iji kakao memiliki kadar serat lignoselulosa yang telah terbiodegradasi, degan pengujian spektrofotometer terlihat pertumbuhan jamur pelapuk putih Phanerochaete chrysosporium dapat hidup dan menghasilkan aktifitas enzim lakase tertinggi pada hari ke-5 dan menurut alat colorimeter menghasilkan $\mathrm{L}=47,82, \mathrm{~A}=9,69, \mathrm{~B}=10,48$ warna tersebut menunjukan tidak adanya perbedaan warna kulit biji kakao dengan kakao.
\end{abstract}

Kata Kunci : Karakterisasi, Kulit Biji Kakao, Biodegradasi, Phanerochaete chrysosporium.

\begin{abstract}
Cocoa bean shell waste has chemical potential such as lignocellulosic fiber content, protein content, carbohydrate content, theobromine content, caffeine content, and tannin content. Cocoa bean shells contain a high lignocellulose fiber, reaching 25.10\%. The lignocellulosic fiber content has the potential to be used as a place to live for Phanerochaete chrysosporium to live and reproduce and degrade bilogically to produce laccase enzymes. The laccase enzyme has a wide range of functions and the need for this enzyme is increasing, but the problem that arises is the high price of the laccase enzyme and is difficult to obtain. Characterization of cocoa bean husk waste begins with the process of reducing the size of the raw material for the cocoa bean husk, biodegradation using Phanerochaete chrysosporium using the solid state fermentation method. Phanerochaete chrysosporium is able to degrade lignin, cellulose and hemicellulose by producing laccase enzymes. Structural and morphological analysis using Scanning electron microscopy (SEM), spectrophotometer, and colorimeter. The purpose of this study was to determine the physical and chemical characterization of cocoa bean shells and to produce laccase enzymes. The research method begins with a preliminary study through observation, literature study to formulate problems, and data collection. The results showed that the SEM results of the structure of the cocoa iji peel had biodegradable lignocellulose fiber content, with spectrophotometer testing, it was seen that the growth of white rot fungus Phanerochaete chrysosporium was viable and produced the highest lacase enzyme activity on day 5 and according to the colorimeter it produced $L$
\end{abstract}


$=47,82, A=9.69, B=10.48$ This color indicates that there is no difference in the color of the skin of

the cocoa beans with the cocoa beans.

Keywords: Characterization, Cocoa Bean Shell, Biodegradation, Phanerochaete chrysosporium.

\section{PENDAHULUAN}

Limbah kulit biji kakao memiliki kandungan lignoselulosa yang cukup tinggi. Lignoselulosa merupakan suatu komples molekul terdiri dari lignin, selulosa, dan hemiselulosa. Limbah kulit biji kakao belum dimanfaatkan secara optimal dan nilai ekonomisnya rendah. Sejauh ini limbah kulit biji kakao hanya dimanfaatkan sebagai pakan ternak dan kompos padahal potensi kimia yang dimiliki kulit biji kakao masih tinggi. Kulit biji kakao mengandung senyawa alkaloid yang disebut theobromine dan senyawa polofenol sebagai zat antioksidan (Utami et al., 2017). Kulit biji kakao memiliki nutrisi yang baik berupa serat, protein dan potensi bioaktif dalam bentuk senyawa polifenol berupa tannin dan antosianin (Minifie, 1999). Kulit biji kakao adalah kulit tipis, lunak dan agak berlendir yang menyelubungi keping biji kakao. Persentasenya berkisar $10-16 \%$ dari keseluruhan bagian biji kakao kering (Fowler, 2009). Menurut Sutardi, (1991) komposisi lignoselulosa kulit biji kakao terdiri $25,10 \%$. Kandungan yang cukup tinggi membuat kulit biji kakao dapat difermentasikan sebagai substrat dalam memproduksi enzim lakase.

Enzim lakase memiliki fungsi yang luas dan kebutuhan akan enzim ini semakin meningkat. Enzim lakase merupakan enzim ligninase yang dapat mendegradasi lignin pada limbah lignoselulosa. Pada penelitian ini digunakan jamur pelapuk putih Phanerochaete chrysosporium. Yang dapat mengsekresikan enzim lignoselulosa. Fungi ini digunakan untuk fermentasi kulit biji kakao dalam bioreaktor fermentasi substrat padat berskala 1 liter. Dalam penelitian ini akan dilakukan optimasi waktu inkubasi untuk memproduksi aktifitas enzim lakase.

Karakteristik fisik dan kimia merupakan faktor penting dalam menentukan mutu kulit biji kakao. Karakteristik fisik seperti keseragaman ukuran bubuk kulit biji kakao dan warna bubuk kulit biji kakao digunakan untuk menggolongkan mutu berdasarkan kenampakan fisik, sedangkan karakteristik kimia digunakan untuk mengetahui kandungan air, kandungan abu, kandungan lemak, kandungan protein, kandungan karbohidrat, kandungan serat, kandungan tannin, kandungan theobromine, kandungan lignoselulosa pada kulit biji kakao dan aktifitas enzim lakase. Terdapat berbagai metode dilakukan untuk tujuan mendapatkan enzim lakase. Metode biodegradasi dilakukan terkait pengembangan degradasi lignin salah satunya dengan pendekatan secara biologi yang memanfaatkan mikroorganisme yang dapat menghasilkan enzim untuk hidrolisis ikatan yang terbentuk antara lignin, selulosa dan hemiselulosa secara ramah lingkungan dan menghasilkan bahan baku yang ramah lingkungan (Chowdhury., et al 2013). Tujuan penelitian ini adalah untuk mengetahui karakterisasi kulit biji kakao secara fisik dan kimia serta menghasilkan enzim lakase. Pelaksanaan penelitian ini menggunakan model deskriptif. Model statistik deskriptif adalah salah satu bagian dari ilmu statistika yang berhubungan dengan aktivitas penghimpunan, penataan, peringkasan dan penyajian data dengan harapan agar data lebih bermakna, mudah dibaca dan mudah dipahami oleh pengguna data. Statistik deskriptif hanya sebatas memberikan deskripsi atau gambaran umum tentang karakteristik objek yang diteliti tanpa maksud untuk melakukan generalisasi sampel terhadap populasi. Kegiatan dalam statistik deskriptif meliputi pengumpulan, pengelompokan dan pengolahan data yang selanjutnya akan menghasilkan ukuranukuran statistik seperti pemusatan data, penyebaran data. Selain itu, data disajikan diringkas dalam bentuk tabulasi atau disajikan dalam bentuk grafik atau diagram. Penggunaan grafik dan diagram 
dimaksudkan agar data yang disajikan lebih menarik dan lebih komunikatif.

\section{METODE}

Penelitian ini merupakan penelitian deskriptif dan experiment. Penelitian ini dilaksanakan di Laboratorium Mikrobiologi Universitas Pasundan. Penelitian ini menggunakan metode solide state fermentation diulang sebanyak tiga kali. Penelitian bertujuan untuk mencari karakteristik kulit biji kakao. Karakteristik pendahuluan yang dilakukan adalah ukuran serbuk kulit biji kakao menjadi 80 mesh yang selanjutnya akan dilakukan pengujian SEM (Scanning electron micriskopy). Kemudian dilakukan penelitian lanjutan untuk mengidentifikasi karakteristik kulit biji kakao secara fisik dan kimia. Tahapan penelitian dilakukan persiapan bahan kulit biji kakao diolah menjadi serbuk dengan cara pengumpulan bahan, sortasi untuk memastikan pengotor dari kulit biji kakao hilang dan tidak ada yang busuk, selanjutnya dihaluskan dengan mesin penggiling (grinder) dan proses pengayakan hingga ukuran 80 mesh. Persiapan pembuatan media Natrium Agar (NA) untuk proses peremajaan jamur pelapuk putih Phanerochaete chrysosporium, sterilisasi media kulit biji kakao. Inkubasi selama 14 hari menggunakan substrat kulit biji kakao dengan metode solid state fermentation (SSF). Teknik pengambilan data dengan menggukur aktifitas enzim lakase setiap hari setiap 24 jam dalam masa inkubasi 14 hari menggunakan alat spektrofotometer.

\section{HASIL DAN PEMBAHASAN}

Penelitian ini menggunakan bahan kulit biji kakao yang diperoleh dari Dusun Gambiran Desa Bunder Kecamatan Patuk Kabupaten Gunung Kidul Yogyakarta. Kulit biji kakao serbuk berukuran 80 mesh. Menurut SNI standar kehalusan dari serbuk kakao yaitu lolos ayakan mesh $200 \mathrm{~b} / \mathrm{b}$ dengan tingkat kelolosan 99,5\%, artinya serbuk kulit biji kakao dengan ukuran 60 mesh sesuai dengan standar SNI karena kurang dari 200 mesh dengan tingkat kelolosan 99,5\% (BPTP Balai Pengkajian Teknologi Pertanian., 2012).

Berikut gambar dari kulit biji yang dilakukan proses SEM (Scanning electron micriskopy) untuk mengetahui karakteristik penampakan fisik kulit biji kakao. Hasil SEM terdapat pada gambar 1 berikut.

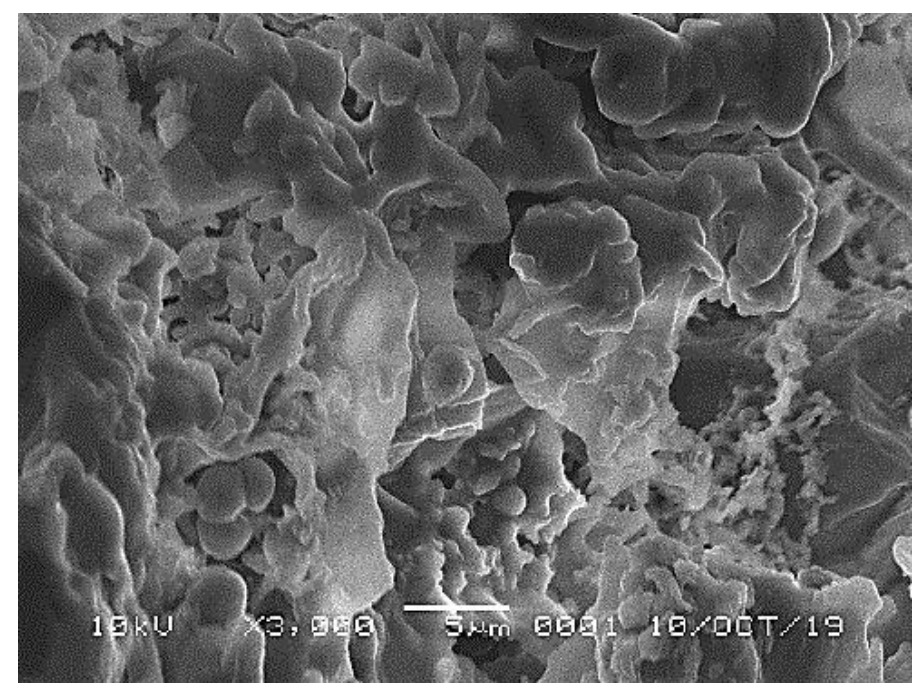

Gambar 1. Kulit Biji Kakao sebelum Biodegradasi 
Setelah dilakukan pengujian SEM maka dilakukan proses selanjutnya berupa proses degradasi kulit biji kakao secara biologi dilakukan dengan metode fermentasi kultur padat (solid state fermentation). Proses fermentasi kultur padat ini, dimaksudkan agar jamur dapat mereduksi kandungan lignin yang terkandung didalam serat kulit biji kakao sehingga serat kulit biji kakao mengalami penurunan kandungan lignin. Jamur yang diinokulasikan untuk mereduksi kandungan lignin dalam serat kulit biji kakao. Berdasarkan proses biodegradasi secara solid state fermentation terhadapkulitbijikakaoyang direndam menggunakan urea $2 \%$ ditambahkan dengan yeast ekstrak kemudian dilakukan sterilisasi selama 120 ${ }^{\circ} \mathrm{C}$ dengan waktu 20 menit kemudian pendinginan dilakukan inkubasi selama 014 hari dengan suhu $28^{\circ} \mathrm{C}$ ditambahkna inokulum Phanerochaete chrysosporium. Hasil inkubasi dilakukan ekstraksi dengan larutan penyangga asetat $\mathrm{pH} 5$, kemudian dishaking selama 2 jam dengan kecepatan 100 rpm menghasilkan cairan dan padatan. Dimana cairan merupakan enzim lakase yang kemudian dilakukan perhitungan aktifitas enzim (Risdianto et al., 2013).

Enzim lakase merupakan enzim yang produksinya paling tinggi dihasilkan Phanerochaete chrysosporium. Enzim lakase merupakan enzim ekstrakselular yang dihasilkan pada saat jamur memasuki fase metabolisme sekunder yang mendorong oleh kekurangan nutrisi nitrogen, karbon, maupun sulpur. Umumnya dilakukan pada saat kadar glukosa rendah, maka kondisi tersebut memicu Phanerochaete chrysosporium untuk menghasilkan enzim ekstraseluler. Keberadaan enzim ekstraseluler tersebut berperan untuk mendegradasi lignin pada struktur lignoselulosa, sehingga selulosa dan hemiselulosa yang terkandung didalamnya dapat dijadikan sebagai sumber karbon kembali untuk pertumbuhan Phanerochaete chrysosporium (Kirk et al., 1986). Diawali pertumbuhan Phanerochaete chrysosporium sumber karbon yang ada didalam medium akan dimanfaatkan untuk pertumbuhan dan pertambahan biomasa jamur. Pada saat konsentrasi sumber karbon mulai terbatas, maka pertumbuhan Phanerochaete chrysosporium mulai melambat dan terhenti sementara. Peralihan metabolisme Phanerochaete chrysosporium dimulai untuk mencari sumber karbon lain dengan cara mendegradasi atau merusak struktur lignin pada limbah lignoselulosa yang dijadikan sebagai substrat pertumbuhan, sehingga memudahkan akses perolehan selulosa maupun hemiselulosa pada limbah lignoselulosa yang akan dijadikan sebagai sumber karbon pengganti dari gula sederhana seperti selulosa maupun hemiselulosa. Enzim ekstraseluler petama kali aktif bekerja dan dihasilkan dalam mendegradasi lignin adalah enzim lakase oleh Phanerochaete chrysosporium (Lestari, 2015).

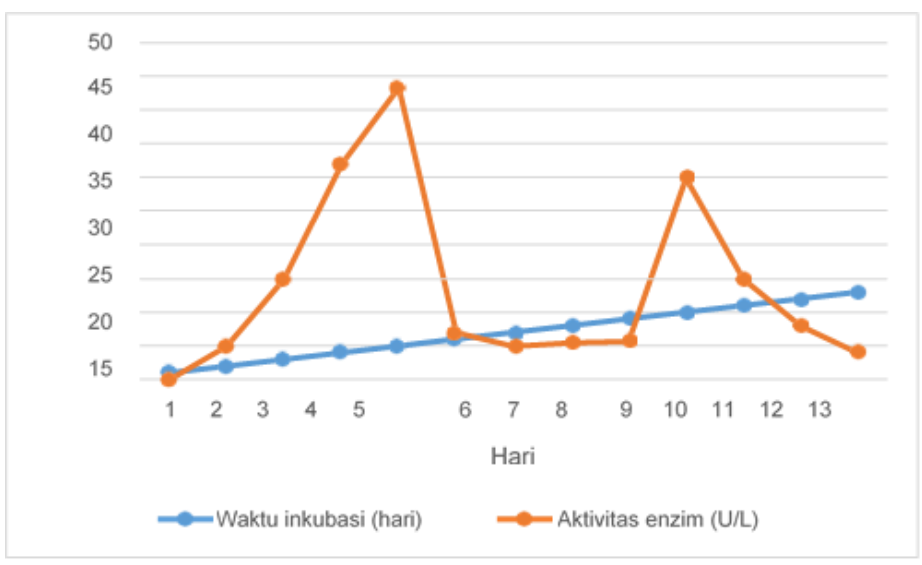

Gambar 2. Kurva Aktivitas Enzim Lakase 
Hasil dari pengukuran aktivitas enzim lakase dapat dilihat pada kurva aktivitas enzim lakase diatas dari perhitungan enzim yang diaplikasikan pada bentuk kurva. Pada awal fermentasi hingga hari ke 5 terjadi peningkatan aktifitas enzim lakase. Diperkirakan Phanerochaete chrysosporium mulai kekurangan sumber karbon dan nitrogen sehingga aktivitas lakase meningkat untuk menguraikan lignin dan mendedahkan selulosa untuk didegradasi (Brijwani et al., 2010). Pada hari ke 6 fermentasi aktivitas lakase mengalami penurunan. Penurunan aktivitas enzim dapat diakibatkan oleh resepsi katabolit. Glukosa yang berasal dari penguraian substrat dapat menghambat sintesis lakase. Mekanisme ini merupakan respon untuk menghemat energi oleh jamur (Piscitelli et al., 2011).

Hasil serbuk kulit biji kakao terdelignifikasi oleh jamur Phanerochaete chrysosporium dilakukan proses SEM kembali untuk melihat karakteristik fisik setelah delignifikasi. Gambar SEM dapat dilihat pada gambar 3 .

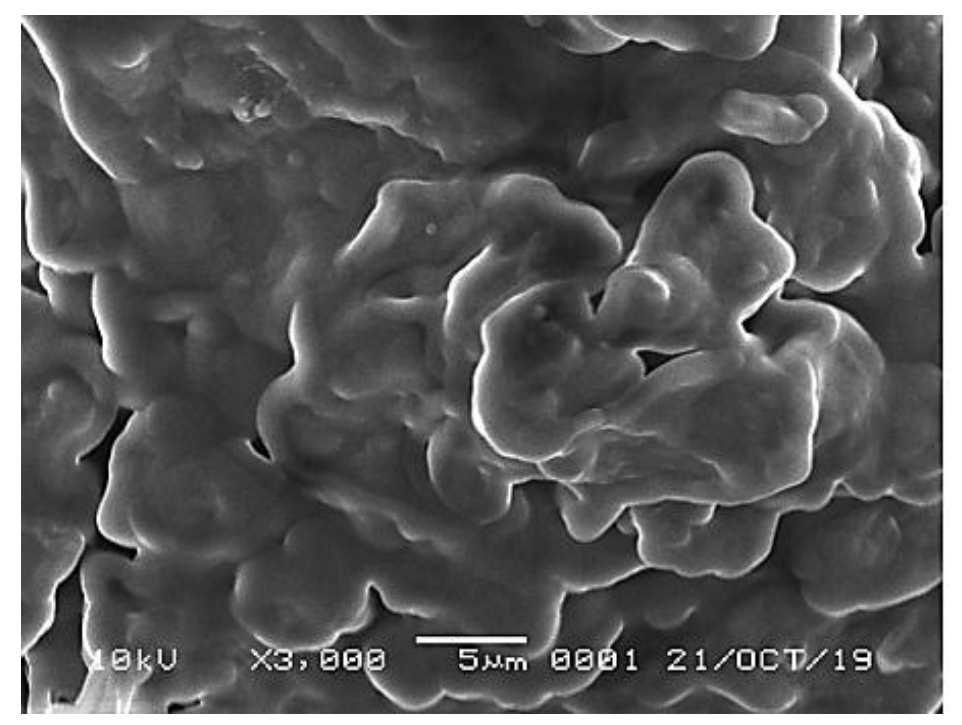

Gambar 3. Kulit Biji Kakao Terbiodegradasi

Pada gambar 3 terlihat bahwa adanya perbedaan karakteristik secara fisik yang dihasilkan oleh foto dari hasil SEM tersebut. Setelah dilakukan proses analisis SEM maka selanjutnya dilakukan pengukuran warna untuk mengetahui standar warna dari serbuk kulit biji kakao. Pengukuran warna dilakukan oleh colorimeter $\mathrm{NH} 310$. Colorimeter NH 310 ini sensitif terhadap setiap cahaya diukur dan sebagian besar warna diserap oleh suatu benda atau zat.

\section{Tabel 1. Hasil Pengukuran Warna Serbuk Kulit bIji Kakao}

\begin{tabular}{cc}
\hline Karakteristik & Calorimeter \\
\hline Warna & $\mathrm{L}=47,82$ \\
& $\mathrm{~A}=9,69$ \\
& $\mathrm{~B}=10,48$
\end{tabular}

Selanjutnya dilakukan pemeriksaan karakteristik kimia kulit biji kakao. Karakteristik kimia kulit biji kakao bertujuan untuk menilai mutu dari kulit biji kakao yang digunakan untuk penelitian. 
Tabel 2. Hasil pengukuran Karakteristik Kimia Biji Kakao Kering

\begin{tabular}{cc}
\hline Karakteristik kimia & Hasil \\
\hline Kadar Air & $4,53 \%$ \\
Kadar Abu & $6,64 \%$ \\
Kadar protein & $16,60 \%$ \\
Kadar Lemak & $8,82 \%$ \\
Kadar Karbohidrat & $54,84 \%$ \\
Kadar Serat & $5 \%$ \\
Kadar Teobromine & $4,3 \%$ \\
Kadar Cafein & $3,1 \%$ \\
Kadar Polifenol & $1,46 \%$ \\
Kadar Tanin & $4,46 \%$ \\
pH meter & 5 \\
\hline
\end{tabular}

Dengan hasil kadar air pada kulit biji kakao 4,53\% yang memenuhi SNI serbuk kakao menurut SNI <5\% dengan melihat kadar air yang dihasilkan sesuai dengan standar dapat dijelaskan bahwa serbuk kulit biji kakao yang digunakan baik dalam penyimpanan yang lama. Kadar lemak pada serbuk kakao 8,82\% yang tidak memenuhi standar SNI serbuk kakao namun karna ini merupakan serbuk kulit biji kakao dengan kadar $8,82 \%$ menunjukan angka yang baik yang tidak mengandung banyak lemak sehingga dapat menjadi alternative substitusi bagi serbuk kakao yang memiliki nilai lemak terlalu tinggi.

Kadar abu, protein, dan karbohidrat memiliki kandungan yang tidak jauh berbeda dengan serbuk kakao keunggulan dari kulit biji kakao memiliki kandungan theobromine, cafein, polifenol, tannin, dan serat tinggi seperti lignin, selulosa, dan hemiselulosa yang tidak dimiliki oleh buah kakao.

\section{KESIMPULAN}

Karakteristik kulit biji kakao menjadikan limbah kulit biji kakao memiliki keunggulan karakteristik secara fisik dan kimia, kulit biji kakao berpotensi digunakan sebagai media pertumbukan jamur pelapuk putih Phanerochaete chrysosporium untuk memproduksi enzim lakase. Aktifitas enzim lakase tertinggi dapat dilihat pada hari ke 5 dengan nilai aktifitas 43,44 U/L.

\section{UCAPAN TERIMAKASIH}

Penelitian ini didanai oleh Penelitian Dosen Pemula Tahun 2020 dari Direktorat Riset dan Pengabdian Kepada Masyarakat Kementrian Riset dan Teknologi/Badan Riset dan Inovasi Nasional.

\section{DAFTAR PUSTAKA}

Minifie, B.W., 1999. Chocolate, Cocoa and Confectionery: Science and Technology, 3rd ed.

Balai Pengkajian Teknologi Pertanian., 2012. Teknologi Pengolahan Biji Kakao Menuju SNI Biji Kakao 012323-2008.

Brijwani, Rigdon, Vadlani, 2010. Fungal laccases: Production, function and aplication in food processing. Enzyme Research, 149748.

Fowler, M.S., 2009. Cocoa Beans: from Tree to Factory., 2nd ed. Oxford, United Kingdom.

Kirk, T.K., Tien, M., Johnsrud, S.C., Eriksson, K.-E., 1986. Lignin degrading activity of Phanerochaete chrysosporium Burds.: comparison of cellulase-negative and other strains. Enzyme and Microbial Technology 8, 75-80. 
https://doi.org/10.1016/0141-

0229(86)90074-8

Lestari, 2015. Penapisan dan Optimasi Produksi Enzim Lignoselulase (MnP dan Lakase) dengan memanfaatkan limbah tandan kosong kelapa sawit (TKKS).

Maiti, S.K., Chowdhury, A., 2013. Effects of Anthropogenic Pollution on Mangrove Biodiversity: A Review. JEP 04, 1428-1434. https://doi.org/10.4236/jep.2013.412 163

Piscitelli, Giardina, Lettera, Pezzela, Sannia, Faraco, 2011. Induction and transcriptional regulation of lacccases in fungi. Current Genomics 12, 104-112.

Risdianto, H., Ronald, O., Cornelius Damar, H., 2013. Optimisasi Produksi Enzim Lakase pada Fermentasi Kultur Padat menggunakan Jamur Pelapuk Putih Marasmius sp.: Pengaruh ukuran partikel, Kelembapan, dan Konsentrasi $\mathrm{Cu}$.

Sutardi, T., 1991. Pemanfaatan Limbah Tanaman Perkebunan sebagai Pakan Ternak Ruminansia.

Utami, R.R., Supriyanto, S., Rahardjo, S., Armunanto, R., 2017. Aktivitas Antioksidan Kulit Biji Kakao dari Hasil Penyangraian Biji Kakao Kering pada Derajat Ringan, Sedang dan Berat. Agritech 37, 89. https://doi.org/10.22146/agritech.10 454 